УДК 504.53.064(477.46)

О. О. Мислюк, к.х.н., доцент, e-mail: omyslyuk13@gmail.com

О. М. Хоменко, к.х.н., доиент, e-mail: homenko@uch.net

О. В. Сгорова, к.т.н., викладач, e-mail: yegorova.ok@gmail.com

В. І. Пидоренко, бакалавр екологї

e-mail: pydorenko313131@gmail.com

Черкаський державний технологічний університет, б-р Шевченка, 460, м. Черкаси, 18006, Україна

\title{
ЕКОЛОГІЧНІ АСПЕКТИ СТАНУ УРБАНОЗЕМІВ
}

Дано оцінку екологічного стану трунтів м. Черкаси за основними фізико-хімічними властивостями. Аналіз екологічного стану трунтів м. Черкаси виявив їх неоднорідність, значне відхилення від оптимальних значень, що характеризує їх як антропогенно і техногенно урбанізовані. Важливими недоліками є низький вміст гумусу, залуження трунту і несприятливі окисно-відновні умови, порушення оптимального співвідношення Кальцію і Магнію у ГВК. У зв'язку з иим потрібно передбачити заходи щодо відновлення структури трунтів та покращення трунтових умов зростання зелених насаджень на території міста, зокрема, гіпсування трунту, внесення органічних добрив, забезпечення зволоження і обмеження випаровування вологи, покращення аераційних умов.

Ключові слова: урбаноземи, хімічна трансформаиія, фізико-хімічні властивості трунту, гумус, рослини.

Вступ. Загальновідомо, що грунт виконує значну кількість екологічних функцій, які забезпечують стабільність як окремих біоценозів, так і біосфери в цілому. Проте техногенне навантаження на грунтові комплекси значно погіршує їх екологічні функції. Особливо гостро проявляються негативні зміни в межах великих міст $[1,2]$. Для урбаноземів характерна фізична й хімічна трансформація, яка проявлясться, перш за все, у руйнації профільної структури, наявності антропогенних включень, підвищенні щільності, зниженні вологоємності, зміні біологічних показників, значень $\mathrm{pH}$, ОВП, вмісту гумусу, накопиченні важких металів тощо [3].

Метою роботи $\epsilon$ екологічне оцінювання сучасного стану урбогрунтів м. Черкаси.

Матеріали і результати досліджень. Літогенною основою ландшафтів м. Черкаси виступають леси і лесовидні суглинки, супіски різного генезису. Грунтовий покрив неоднорідний, легкого механічного складу 3 переважанням великого і середнього піску, наявністю включень антропогенного характеру. Найбільш поширені чорноземи типові слабо гумусовані і лучно-чорноземні грунти на лесових породах. Грунти міста зазнають значно- го аеротехногенного навантаження [4] і містять багато хімічних ксенобіотиків $[5,6]$. Діагностика показників грунтів, які є визначальними для оцінювання їх екологічного стану, виконання ними агроекологічних функцій, дасть можливість визначити оптимальні та критичні значення для сталого функціонування міських ландшафтів та запропонувати до реалізації найефективніші й своєчасні заходи.

Дослідження фізико-хімічних властивостей грунтів проводилися на 32 ділянках в різних функціональних зонах міста (рисунок 1) за стандартними методиками.

Відбір проб зразків грунту здійснювали методом конверта 3 глибини 0-20 см (верхні гумусо-акумулятивні горизонти). Статистичну обробку результатів виконано за допомогою пакета MS Excel.

Результати досліджень властивостей урбаноземів подано в таблиці 1.

Важливим фактором стійкості грунтів до антропогенних впливів $є$ вміст гумусу, який сприяє оструктуренню грунтів та оптимізації фізичних властивостей, підвищує поглинальну здатність і буферність, акумулює біофільні хімічні елементи й енергію. 


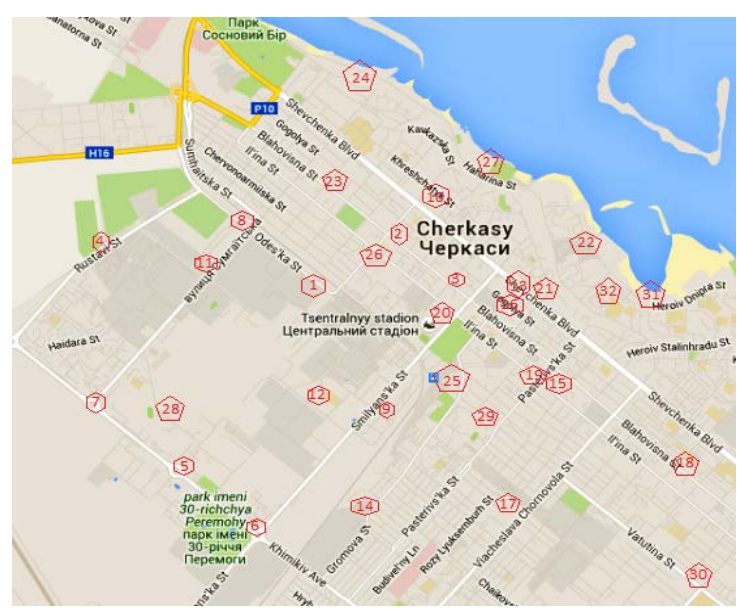

Рисунок 1 - Карта-схема розташування ділянок

Таблиця 1 - Фізико-хімічні властивості урбаноземів міста Черкаси

\begin{tabular}{|c|c|c|c|c|c|c|}
\hline $\begin{array}{c}\text { № } \\
\text { ділянки }\end{array}$ & $\begin{array}{c}\text { Вміст } \\
\text { гумусу, \% }\end{array}$ & $\mathrm{pH}_{\text {вод. }}$ & $\begin{array}{c}\text { ОВП, } \\
\text { мВ }\end{array}$ & $\begin{array}{c}\mathrm{Mg}^{2+} \text { обм., } \\
\text { мг-екв/100 г } \\
\text { грунту }\end{array}$ & $\begin{array}{c}\mathrm{Ca}^{2+} \text { обм., } \\
\text { мг-екв } / 100 \text { г } \\
\text { грунту } \\
\end{array}$ & $\begin{array}{c}\mathrm{K}^{+} \text {розч., } \\
\text { мг-екв/100 г } \\
\text { грунту } \\
\end{array}$ \\
\hline 1 & 1,02 & 7,65 & 259 & 0,0 & 7,8 & 6,2 \\
\hline 2 & 0,65 & 7,80 & 258 & 2,2 & 5,6 & 0,3 \\
\hline 3 & 0,80 & 10,90 & 254 & 0,8 & 5,2 & 0,1 \\
\hline 4 & 0,49 & 7,25 & 264 & 0,8 & 4,0 & 0,6 \\
\hline 5 & 0,71 & 7,35 & 256 & 0,0 & 6,2 & 0,4 \\
\hline 6 & 1,53 & 7,05 & 260 & 1,8 & 6,8 & 0,5 \\
\hline 7 & 0,13 & 6,70 & 256 & 2,4 & 6,2 & 1,5 \\
\hline 8 & 0,82 & 6,55 & 254 & 1,4 & 6,6 & 0,6 \\
\hline 9 & 0,65 & 7,75 & 252 & 0,6 & 6,0 & 0,1 \\
\hline 10 & 0,36 & 8,94 & 259 & 0,4 & 7,0 & 0,6 \\
\hline 11 & 0,32 & 7,80 & 259 & 3,8 & 7,2 & 0,5 \\
\hline 12 & 0,65 & 8,15 & 256 & 2,6 & 6,2 & 2,8 \\
\hline 13 & 1,42 & 8,60 & 264 & 3,0 & 6,6 & 0,2 \\
\hline 14 & 0,54 & 8,35 & 266 & 4,2 & 5,8 & 0,2 \\
\hline 15 & 1,04 & 7,45 & 257 & 1,6 & 3,8 & 0,1 \\
\hline 16 & 1,09 & 8,86 & 260 & 2,8 & 6,4 & 0,5 \\
\hline 17 & 2,04 & 7,85 & 259 & 4,5 & 9,0 & 1,1 \\
\hline 18 & 0,91 & 7,35 & 264 & 1,7 & 9,9 & 0,2 \\
\hline 19 & 0,04 & 7,45 & 254 & 5,8 & 6,4 & 2,6 \\
\hline 20 & 0,59 & 6,85 & 278 & 5,3 & 9,7 & 0,3 \\
\hline 21 & 1,61 & 7,65 & 255 & 2,6 & 5,9 & 0,2 \\
\hline 22 & 0,71 & 7,25 & 277 & 10,4 & 4,2 & 0,7 \\
\hline 23 & 0,46 & 7,60 & 266 & 3,8 & 6,2 & 0,3 \\
\hline 24 & 0,16 & 7,40 & 267 & 6,1 & 7,7 & 0,2 \\
\hline 25 & 0,37 & 7,70 & 258 & 4,9 & 5,3 & 0,2 \\
\hline 26 & 1,66 & 7,85 & 256 & 5,5 & 5,3 & 0,4 \\
\hline 27 & 0,54 & 7,55 & 258 & 2,4 & 6,6 & 0,6 \\
\hline 28 & 3,01 & 6,45 & 266 & 7,2 & 5,9 & 0,3 \\
\hline 29 & 1,43 & 8,10 & 267 & 0,1 & 10,1 & 0,4 \\
\hline 30 & 0,03 & 8,45 & 252 & 6,9 & 7,7 & 0,4 \\
\hline 31 & 0,27 & 7,80 & 257 & 4,7 & 5,1 & 0,7 \\
\hline 32 & 0,84 & 7,55 & 275 & 0,1 & 9,9 & 0,3 \\
\hline
\end{tabular}


На геохімічному бар'єрі гумусового горизонту грунту відбувається депонування важких металів. Основні показники гумусового стану грунтів належать до консервативних властивостей грунту, кількісні характеристики яких формуються тривалий час і настільки ж довго зберігаються. Однак вплив урбанізації на грунти $€$ настільки інтенсивним і тривалим, що відбуваються зміни і найбільш стійких властивостей. Хімічні забруднення, впливаючи на склад і властивості гумусових речовин, можуть призводити до порушень екологічної рівноваги в біогеоценозах. Не менш важливою $\epsilon$ роль гумусового стану грунтів урболандшафтів [7].

Вміст гумусу у грунтах м. Черкаси (рисунок 2) $є$ переважно дуже низьким, коливається у межах 0,03-3,01 \% за середнього значення 0,84\%, стандартне відхилення - 0,67, дисперсія - 0,41, коефіцієнт варіації - $76 \%$.

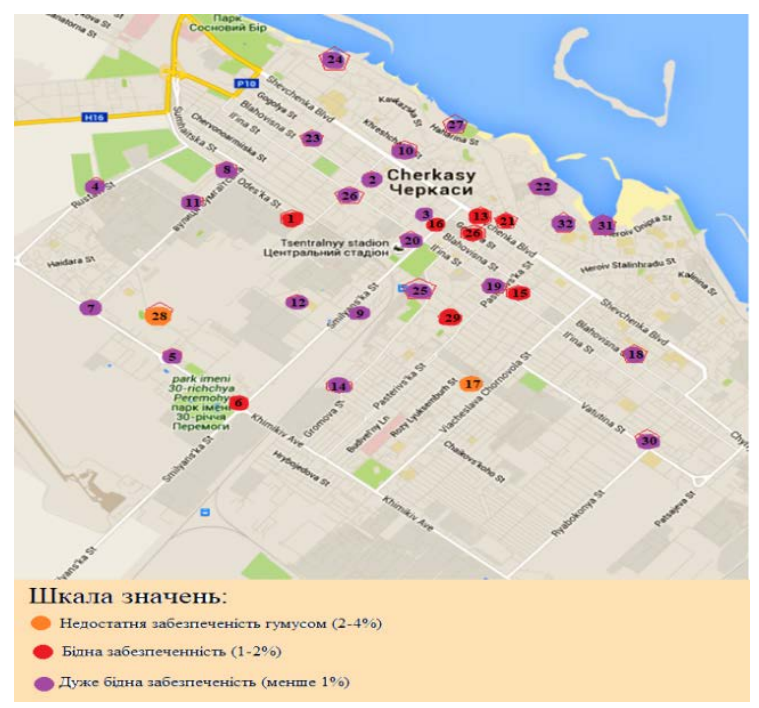

Рисунок 2 - Розподіл гумусу в грунтах

Групування грунтів за вмістом гумусу свідчить, що недостатню забезпеченість гумусом (2-4 \%) має 6,25 \% досліджених грунтових зразків, бідну (1-2 \%) - 25 \% і вкрай бідну (менше $1 \%$ ) - 69 \% (рисунок 3 ).

Такі низькі показники пояснюються тим, що у місті відбувається забруднення i руйнування верхнього родючого шару грунту, надходить велика кількість піску, яким посипаються дороги взимку, процес гумусоутворення практично відсутній через те, що опалі листки, дрібні гілки та плоди прибираються i, таким чином, поповнення органічної складової грунту за їх рахунок не відбувається, процеси розпаду, гуміфікації та мінералізації навіть тих рослинних решток, що не були вилучені, гальмуються внаслідок дії всього комплексу антропогенних впливів [8].

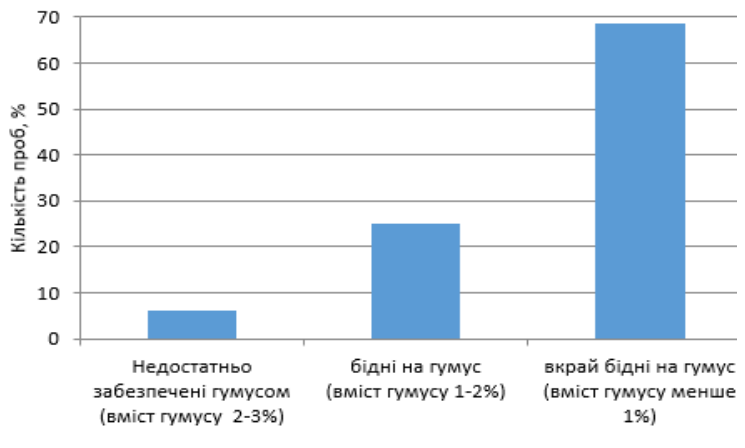

Рисунок 3 - Забезпеченість гумусом грунтів

Узагальнюючим екологічним показником, який характеризує поживний режим грунту, впливає на ріст і розвиток рослин, на міграційні властивості важких металів, $є$ актуальна кислотність грунтового розчину.

Актуальна кислотність грунтів ( $\mathrm{pH}_{\text {вод.) }}$ на дослідних ділянках м. Черкаси коливається в межах від 6,45 до 10,90 при середньому значенні 7,20, стандартне відхилення - 0,83, дисперсія - 0,69. За величиною $\mathrm{pH}$ грунти характеризуються однорідністю - коефіцієнт варіації $\mathrm{Cv}=11 \%$. Переважно досліджені грунти мають слабколужне і нейтральне середовище (рисунок 4).

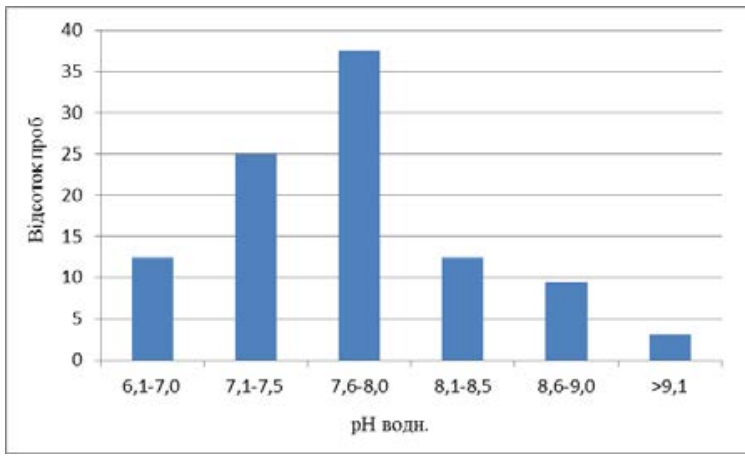

Рисунок 4 - Розподіл грунтів за кислотністю

У міських умовах грунти зазвичай лужні [1, 9-12], хоча трапляються і кислі [13-15]. В цілому процес незначного залуження грунту сприятливо позначається на його властивості та родючості, зокрема, знижується ступінь рухливості металів, що позитивно впливає на ріст і розвиток рослин, сприяє активізації мікробного співтовариства. Однак подальше залуження (при $\mathrm{pH}>7,5$ ) спричиняє погіршення структури грунту, порушення рівноваги грунтово-геохімічних процесів, що призводить до 
зниження стійкості екосистеми, і являє собою цілий ряд проблем для рослин, включаючи дисбаланс поживних речовин, який не сприяє нормальному розвитку кореневої системи деревних рослин, токсичність іонів тощо (рисунок 5) $[8,16]$. При $\mathrm{pH}>8,0$ грунт має погані фізичні властивості, фільтрація і перколяція надзвичайно утруднені. Утворюються важкорозчинні сполуки, що знижує доступність для рослин елементів живлення, можливе розчинення органічних речовин грунту (гумусу), грунт стає малопридатним для зростання рослин [17].

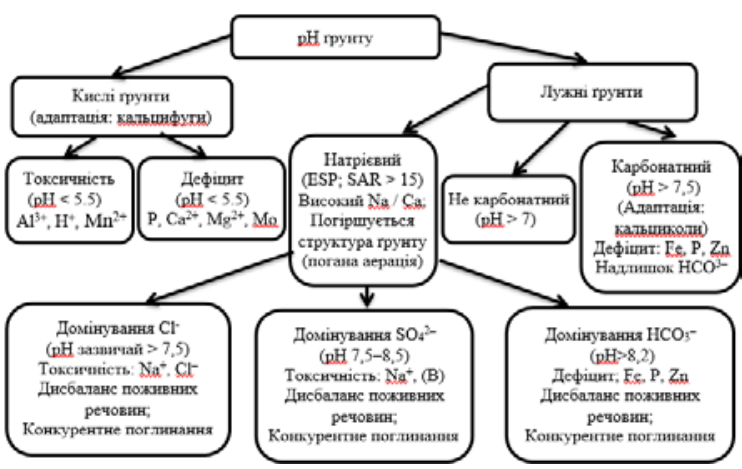

Рисунок 5 - Реакції рослин на грунтах 3 неоптимальним значенням рН

За показником $\mathrm{pH}$ на деяких досліджених ділянках у м. Черкаси спостерігаються неоптимальні умови щодо живлення рослин необхідними макро- та мікроелементами (рисунок 6).

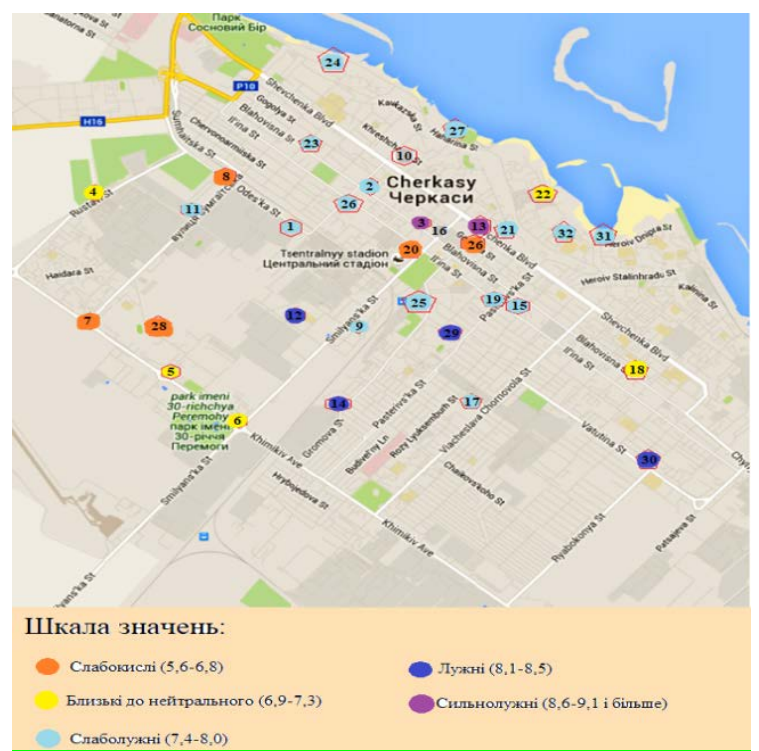

Рисунок 6 - Характеристика кислотноосновних властивостей грунтів
Залуження грунтів м. Черкаси, імовірно, зумовлене застосуванням взимку піщаносольових сумішей при ожеледицях, а також викидами підприємств і автотранспорту, які 3 опадами $з$ часом потрапляють у грунт. Лужність грунтів порушує засвоювання елементів живлення рослинами та може призвести до погіршення стану зелених насаджень і невиконання ними своїх функцій.

За участю іонів водню відбувається багато окисно-відновних реакцій у грунтах, тому від значень $\mathrm{pH}$ залежить окисно-відновний стан грунтів, який впливає на грунтоутворення, регулюючи процес деструкції органічних залишків, темпи нагромадження i характер гумусових речовин, а також рухомість і біологічну доступність поживних речовин (сполук Нітрогену і Фосфору, мікроелементів) у системі грунт-рослина. Окисно-відновний потенціал (ОВП) є інтегральним показником оцінювання стабільності окисно-відновних процесів грунту, які впливають на його здатність підтримувати екологічну рівновагу у системах грунт-атмосфера і грунт-рослина $[18,19]$.

Окисно-відновний потенціал грунтів варіював від 252 до 287 мВ при середньому значенні 262 мВ (стандартне відхилення - 7,3, дисперсія - 52,6, коефіцієнт варіації - $3 \%$ ). Низькі значення ОВП грунтів м. Черкаси можуть бути зумовлені режимом зволоження, кількістю органічної речовини, мікробіологічною активністю, поганою аерацією грунту через його переущільнення.

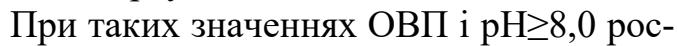
лини можуть відчувати дефіцит $\mathrm{Fe}, \mathrm{Mn}$. У грунті переважатимуть процеси денітрифікації (рисунок 7).

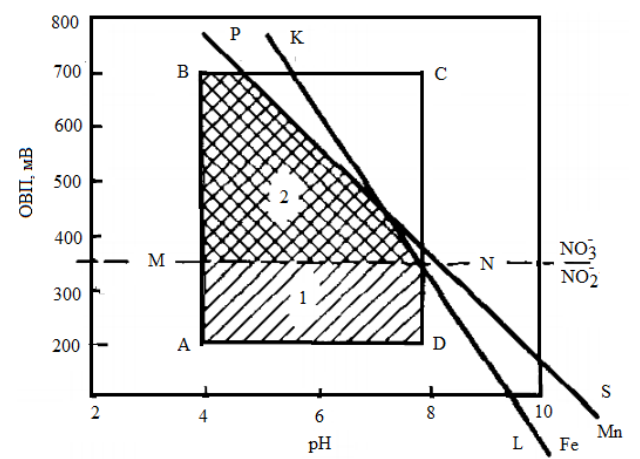

1 - область нормального постачання рослин залізом і марганцем; 2 - область нормального постачання рослин залізом, марганцем і нітратами

Рисунок 7 - Граничні умови нормального живлення рослин (за І. П. Сердобольским) [19] 
Важливу роль у процесах грунтоутворення відіграє Кальцій. Він входить до складу грунтового вбирного комплексу (ГВК), бере участь в обмінних реакціях грунтового розчину, зумовлює високу буферність грунту в кислому інтервалі середовища. Найкращі умови для живлення рослин створюються при переважанні у складі ҐВК катіонів $\mathrm{Ca}^{2+}$. Часткова заміна $\mathrm{Ca}^{2+}$ на $\mathrm{Mg}^{2+}$ у ІВК призводить до погіршення водно-фізичних властивостей грунтів, якісного складу гумусу, що зумовлює зниження їх родючості [1]. При нестачі $\mathrm{Ca}^{2+}$, в першу чергу, страждає коренева система рослин: ріст коріння припиняється, не утворюються бічні корінці та фізіологічно активні кореневі волоски, корені ослизнюються і темніють. Крім того, іони $\mathrm{Ca}^{2+}$ виконують важливу роль у зміні спрямованості метаболічних процесів в організмі рослин в умовах дії стресових чинників [8].

Проведені дослідження засвідчили, що у складі ГВК вміст $\mathrm{Ca}^{2+}$ коливався в межах від 3,80 до 10,12 мг-екв/100 г грунту при середньому значенні 6,60, стандартне відхилення 1,66 , дисперсія - 2,77, коефіцієнт варіації $25 \%$. Вміст $\mathrm{Mg}^{2+}$ варіюе від 0,00 до 10,40 мгекв/100 г грунту при середньому значенні 3,14 (стандартне відхилення - 2,50, дисперсія 6,26, коефіцієнт варіації - 80 \%).

Йони $\mathrm{Mg}^{2+} \epsilon$ важливими для росту і розвитку рослин, як і йони $\mathrm{Ca}^{2+}$. У той же час висока концентрація $\mathrm{Mg}^{2+}$ може негативно впливати на водоміцність грунтових агрегатів, обмежувати надходження Mn для рослин, дефіцит якого призводить до хлорозу і некрозу листків і стебел [8].

У складі увібраних катіонів чорноземів типових і лучно-чорноземних грунтів Лісостепової зони переважає обмінний кальцій. Зазвичай ГВК на 70-85 \% насичений $\mathrm{Ca}^{2+}$, і тільки у солонцювато-солончакуватих грунтах фіксується підвищений вміст обмінного $\mathrm{Mg}^{2+}$ [20]. За результатом досліджень для багатьох грунтів м. Черкаси характерний більший вміст $\mathrm{Mg}^{2+}$ порівняно $3 \mathrm{Ca}^{2+}$ (рисунок 8).

Привертає увагу i значна неоднорідність досліджених грунтів за вмістом $\mathrm{Mg}^{2+}$ (коефіцієнт варіації - 80 \%). Ймовірно це обумовлено тим, що взимку головні магістралі міста обробляють сумішшю магній хлоридом і натрій хлоридом для боротьби із ожеледицею, а також вимиванням цих іонів з ГВК у процесах нейтралізації іонів Гідрогену в грунтовому розчині.

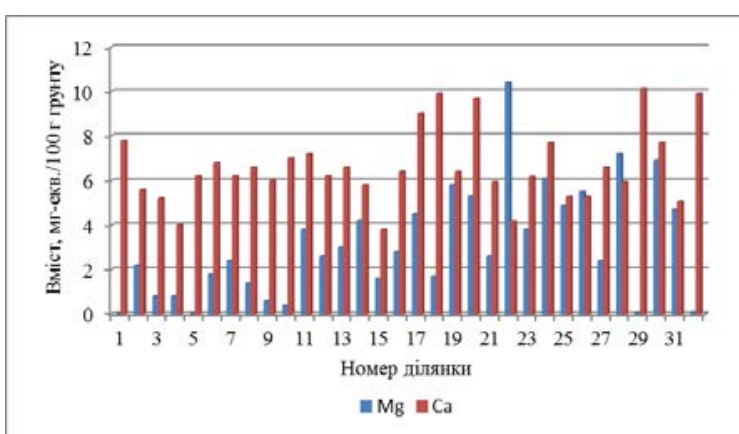

Рисунок 8 - Вміст обмінного Кальцію і Магнію

Калій відноситься до органогенів, необхідних для розвитку рослин, він є одним із трьох макроелементів, необхідних рослинам у найбільших кількостях. Калій підвищує стійкість рослин до шкідників і хвороб, регулює водний режим та підвищує стійкість до посух, покращує розвиток кореневої системи. За вмістом Калію грунти м. Черкаси характеризуються дуже високою неоднорідністю, але переважно забезпечені цим важливим елементом живлення рослин. Відомо, що за валовими формами поживних речовин лучночорноземні грунти наближаються до чорноземів, а в зоні недостатнього зволоження навіть перевищують їх. Не поступаються вони чорноземам і за вмістом рухомих поживних речовин [20].

Вміст Калію коливається в межах від 0,12 до 6,20 при середньому значенні 0,59 мгекв/100 г грунту, стандартне відхилення 0,67, дисперсія - 1,39, коефіцієнт варіації $95 \%$. Висока неоднорідність досліджених грунтів за вмістом $\mathrm{K}^{+}$пояснюється відмінностями рослинного покриву модельних ділянок. Відомо, що Калій швидко засвоюється рослинами.

Низький вміст гумусу, залуження грунтів, несприятливі окисно-відновні умови, незбалансованість поживних елементів можуть робити істотний вплив на стійкість урбоекосистем м. Черкаси, на розвиток зелених насаджень. Відомо, що при зміні концентрації будь-якого елемента в урбопедосистемі обов'язково змінюється концентрація всіх інших елементів, що, безумовно, відбивається на стані всього біогеоценозу, важливим структурним компонентом якого $є$ грунт [21].

Висновки. Аналіз екологічного стану грунтів м. Черкаси виявив їх неоднорідність, значне відхилення від оптимальних значень, що характеризує їх як антропогенно і техногенно урбанізовані. Важливими недоліками $\epsilon$ 
низький вміст гумусу, залуження грунту i несприятливі окисно-відновні умови, порушення оптимального співвідношення Кальцію і Магнію у ГВК.

У зв'язку з цим потрібно передбачити заходи 3 відновлення структури грунтів та покращення грунтових умов зростання зелених насаджень на території міста, зокрема, гіпсування грунту, внесення органічних добрив, забезпечення зволоження i обмеження випаровування вологи, покращення аераційних умов.

Варто враховувати наведені вище чинники для покращення існуючого стану рослин та при створенні нових насаджень під час розроблення генерального плану озеленення м. Черкаси відділом із благоустрою міста Департаменту житлово-комунального комплексу Черкаської міської ради.

\section{Список літератури}

[1] В. І. Тригуб, С. В. Бочевар, та А. М. Купчик, "Грунтово-екологічні особливості міських грунтів (на прикладі м. Одеси)", Вісник Одеського національного університету. Серія: Географічні та геологічні науки, т. 21, вип. 1, с. 98-109, 2016.

[2] О. В. Мірзак, "Досвід дослідження грунтів великих промислових центрів степової зони України (на прикладі м. Дніпропетровська)", Грунтознавство, т. 1. № 12, c. 87-92, 2001.

[3] Soil in the city. Urban soil management strategy. City of Stuttgart, Germany, 2012. [Online]. Available: https://www.researchgate.net/ publication/280919874_Soil_in_the_City_Urb an_Soil_Management_Strategy

[4] О. О. Мислюк, С. В. Мислюк, та Л. М. Соломка, "Оцінка впливу викидів Черкаської ТЕЦ на стан урболандшафтів", Вісник Одеського національного університету. Хімія, т. 15, вип. 12-13, с. 4753, 2010.

[5] О. Ю. Шейкіна, та О. О. Мислюк, "Екологічна оцінка забруднення міських грунтів важкими металами вздовж основних транспортних магістралей міста Черкаси", Екологія довкілля та безпека життедіяльності, № 1, с. 61-65, 2008.

[6] Н. М. Корнелюк, "Особливості акумулювання важких металів вегетативними органами Chenopodium album L. в умовах техногенного забруднення грунтів м. Черкаси", Вісник Кременчуцьького на- цііонального університету, вип. 2 (115), c. 93-100, 2019.

[7] Г. В. Тітенко, та М. І. Кулик, "Гумусовий горизонт міських грунтів як геохімічний бар'єр в урболандшафті", Людина та довкілля. Проблеми неоекологї, № 1-2, с. 130-136, 2012.

[8] О. Г. Луцишин, та ін. "Фізико-хімічні властивості грунтів в умовах Київського мегаполісу", Доповіді Національної академії наук України, № 3, с. 197-204, 2011.

[9] Susan D. Day, Phillip Eric Wiseman, Sarah B. Dickinson, J. Roger Harris, "Tree root ecology in the urban environment and implications for a sustainable rhizosphere", Arboriculture \& Urban Forestry, vol. 36 (5), pp. 193-205, 2010.

[10] Т. К. Клименко, "Вплив грунтових властивостей на розподіл валових форм важких металів у грунтах урбосистем м. Дніпродзержинська", Збірник наукових працьь НГУ, № 38, с. 222-227, 2012.

[11] Л. О. Середа, Л. А. Яблонских, и С. А. Куролап, "Оценка экологогеохимического состояния почвенного покрова городского округа города Воронеж", Вестник Воронежского государственного университета. Серия: География. Геоэкология, № 4, с. 59-65, 2015.

[12] A. Kazlauskaite-Jadzevice, J. Volungevicius, V. Gregorauskiene, and S. Marcinkonis, "The role of $\mathrm{pH}$ in heavy metal contamination of urban soil", Journal of Environmental Engineering and Landscape Management, vol. 22, iss. 4, pp. 311-318, 2014.

[13] E. Hajduk, and Ja. Kaniuczak, "Microelements in soils and in leaves of selected tree species in an industrial urban area", Journal of Elementology, vol. 19, iss. 4, pp. 10011020, 2014.

[14] M. Alamgir, M. Islam, N. Hossain, M. G. Kibria, and M. M. Rahman, "Assessment of heavy metal contamination in urban soils of Chittagong city, Bangladesh: a critical review", International Journal of Plant \& Soil Science, vol. 7, iss. 6, pp. 362-372, 2015.

[15] M. Kharytonov, O. Titarenko, and V. Khlopova, "Assessment of aerotechnogenic pollution of soils in area of industrial enterprises activty of Pavlograd city", Екологічна безпека, № 1 (19), с. 37-40, 2015.

[16] A. Läuchli, and S. R. Grattan, "Soil pH Extremes", in Plant Stress Physiology, Sha- 
bala S., Ed. Cambridge, MA: CAB International. 2012, pp. 194-209.

[17] Методические указания по оценке городских почв при разработке градостроительной и архитектурно-строительной документации. Москва, 2003.

[18] А. Е. Возбуцкая, Химия почвы. Москва: Высшая школа, 1968.

[19] 3. Г. Гамкало, "Екологічна інформативність окисно-відновного потенціалу грунту агрофітоценозів", Наукові записки Віннииького державного педагогічного університету. Серія географія, вип. 3, с. 8289, 2002.

[20] А. М. Польовий, А. I. Гуцал, та О. О. Дронова, Грунтознавство. Одеса: Екологія, 2013.

[21] В. А. Горбань, "Співвідношення екологічних функцій грунтів та їх екологічних властивостей", Грунтознавство, т. 9, № 1-2 (12), с. 124-127, 2008.

\section{References}

[1] V. I. Trygub,

S. V. Bochevar, and A. M. Kupchik, "Soil and ecological peculiarities of urban soils (on the example of Odesa city), Visnyk Odeskoho natsionalnoho universytetu. Ser.: Geografichni ta geologichni nauky, vol. 21, iss. 1, pp. 98-109, 2016 [in Ukrainian].

[2] O. V. Mirzak, "Experience of the investigation of the great industrials centers of the steppe zone of Ukraine (on the example of Dnipropetrovsk city). Gruntoznavstvo, No. 1-2, pp. 87-92, 2001 [in Ukrainian].

[3] Soil in the city. Urban soil management strategy. City of Stuttgart, Germany, 2012. [Online]. Available: https://www.researchgate.net/ publication/280919874_Soil_in_the_City_

Urban_Soil_Management_Strategy

[4] O. O. Myslyuk, E. V. Myslyuk, and L. M. Solomka, "Assessment of impact of Cherkasy CHP plant emissions on urbolandscapes". Visnyk Odeskoho natsionalnoho universytetu. Ser.: Chemistry, vol. 15, iss. 12-13, pp. 47-53, 2010 [in Ukrainian].

[5] O. Yu. Shejkina, and O. O. Myslyuk, "Ekological assessment of urban soil contamination by heavy metals along the main transport roads of Cherkasy city", Ekologija dovkillja ta bezpeka zhittyedijal'nosti, no. 1 , pp. 61-65, 2008 [in Ukrainian].

[6] N. M. Kornelyuk, "Peculiarities of accumulation of heavy metals in Chenopodium album $\mathrm{L}$. vegetative bodies in the conditions of technogenic pollution of soils of Cherkasy city", Visnyk Kremenchukskoho natsionalnoho universytetu im. Myhaila Ostrohradskoho, iss. 2 (115), pp. 93-100, 2019 [in Ukrainian].

[7] A. V. Titenko, and M. I. Kulik, "Humus horizon of urban soils as a geochemical barrier in urban landscape", Lyudyna ta dovkillya. Problemy neoekolohiyi, no. 1-2, pp. 130-136, 2012 [in Ukrainian].

[8] O. G. Lutsyshyn, et al., "Physical and chemical properties of soils under conditions of Kyiv megalopolis", Dopovidi Natsionalnoyi akademiyi nauk Ukrayiny, no. 3, pp. 197204, 2011 [in Ukrainian].

[9] Susan D. Day, Phillip Eric Wiseman, Sarah B. Dickinson, and J. Roger Harris, "Tree root ecology in the urban environment and implications for a sustainable rhizosphere", Arboriculture \& Urban Forestry, vol. 36 (5), pp. 193-205, 2010.

[10] T. K. Klimenko, "The influence of soil properties on the allocation of gross forms of heavy metals in the soils of urban systems of Dniprodzerzhyns'k city", Zbirnyk naukovyh prac' NGU, no. 38, pp. 222-227, 2012 [in Ukrainian].

[11] L. O. Sereda, L. A. Yablonskikh, and S. A. Kurolap, Assessment of ecological and geochemical situation of soil cover in urban district of Voronezh city. Vestnik Voronezhskogo gosudarstvennogo universiteta. Serija: Geographiya. Geoekologiya, no. 4, pp. 59-65, 2015 [in Russian].

[12] A. Kazlauskaite-Jadzevice, J. Volungevicius, V. Gregorauskienè, and S. Marcinkonis, "The role of $\mathrm{pH}$ in heavy metal contamination of urban soil", Journal of Environmental Engineering and Landscape Management, vol. 22, iss. 4, pp. 311-318, 2014.

[13] E. Hajduk, and Ja. Kaniuczak, "Microelements in soils and in leaves of selected tree species in an industrial urban area", Journal of Elementology, vol. 19, iss. 4, pp. 10011020, 2014.

[14] M. Alamgir, M. Islam, N. Hossain, M. G. Kibria, and M. M. Rahman, "Assessment of heavy metal contamination in urban soils of Chittagong city, Bangladesh: a critical review", International Journal of Plant \& Soil Science, vol. 7, iss. 6, pp. 362-372, 2015.

[15] M. Kharytonov, O. Titarenko, and V. Khlopova, "Assessment of aerotechnogenic pollution of soils in area of industrial 
enterprises activty of Pavlograd city", Ekologichna bezpeka, no. 1 (19), pp. 37-40, 2015.

[16] A. Läuchli, and S. R. Grattan, "Soil pH Extremes", in Plant Stress Physiology, Shabala S., Ed. Cambridge, MA: CAB International. 2012, pp. 194-209.

[17] Methodical recommendations on the assessment of urban soils in the development of urban, architectural and building documentation. Moscow, 2003 [in Russian].

[18] A. E. Vozbuckaya, Soil chemistry. Moscow: Vysshaya shkola, 1968 [in Russian].
[19] Z. H. Hamkalo, "Ecological informativity of redox potential of soil agrophytocenosis", Naukovi zapysky Vinnytskoho derzhavnoho pedahohichnoho universytetu im. Mykhaila Kotsiubynskyi State Pedagogical University, iss. 3, pp. 82-89, 2002 [in Ukrainian].

[20] A. M. Polovyi, A. I. Hutsal, and O. O. Dronova, Soil science. Odesa: Ekolohiia, 2013 [in Ukrainian].

[21] V. A. Gorban, "Ecological soil characteristics and their correlations", Soil science, vol. 9, no. 1-2 (12), pp. 124-127, 2008 [in Ukrainian].

O. O. Myslyuk, Ph. D., associate professor, e-mail: omyslyuk13@gmail.com

O. M. Khomenko, Ph. D., associate professor, e-mail: homenko@uch.net

O. V. Yehorova, Ph. D., lecturer, e-mail: yegorova.ok@gmail.com V. I. Pydorenko, bachelor of Ecology, e-mail: pydorenko313131@gmail.com Cherkasy State Technological University Shevchenko blvd, 460, Cherkasy, 18006, Ukraine

\section{ENVIRONMENTAL ASPECTS OF URBAN SOILS}

Physical and chemical transformation is typical for urban soils, that considerably aggravate their agroecological functions. The purpose of this work consists in ecological assessment of the current state of urban soils of Cherkasy. The city soils have a significant man-made load and contain many chemical xenobiotics. Diagnostics of the indicators of urban soils, which are crucial for assessing their ecological status and their agroecological functions, will provide an opportunity to determine the optimal and critical values for the sustainable functioning of urban landscapes and to propose the most effective and timely measures to be implemented.

The urban soils analysis has shown that the humus content varies within the range of 0.03$3.01 \%$, with an average value of $0.84 \%$, a standard deviation of 0.67 , a dispersion of 0.41 , a variation coefficient of $76 \% .6 .25 \%$ of the studied soil samples have insufficient supply of humus (2-4\%), $25 \%$ have poor supply (1-2\%) and $69 \%$ have extremely poor supply (less than $1 \%$ ). The active acidity $(\mathrm{pH})$ varies from 6.45 to 10.90 with an average value of 7.20, a standard deviation of 0.83 , a dispersion of 0.69 , a variation coefficient of $11 \%$. The soils mostly have a weakly alkaline and neutral environment. The oxidation-reducing potential varies from 252 to $287 \mathrm{mV}$, with an average value of $262 \mathrm{mV}$ (standard deviation of 7.3, a dispersion of 52.6, a variation coefficient of $3 \%$ ). The ratio of $\mathrm{Ca}^{2+}$ and $\mathrm{Mg}^{2+}$ cations in soil adsorption complex is not optimal. The content of $\mathrm{Ca}^{2+}$ ranges from 3.80 to $10.12 \mathrm{mg}$-eq. $/ 100 \mathrm{~g}$ of soil with an average value of 6.60, a standard deviation of 1.66, a dispersion of 2.77, a variation coefficient of $25 \%$. The content of $\mathrm{Mg}^{2+}$ varies from 0.0 to $10.40 \mathrm{mg}$-eq. $/ 100 \mathrm{~g}$ of soil with an average value of 3.14 (standard deviation of 2.50, a dispersion of 6.26, a variation coefficient of $80 \%$ ). The content of $\mathrm{K}^{+}$ranges from 0.12 to 6.20 with an average value of $0.59 \mathrm{mg}$-eq. $/ 100 \mathrm{~g}$ of soil, a standard deviation of 0.67 , a dispersion of 1.39, a variation coefficient of $95 \%$.

The soils have a significant deviation from optimal values and that characterizes them as anthropogenically and technogenically urbanized. There is a need in soil gypsuming, organic fertilizers, moisture supply and reduction of moisture evaporation, improvement of aeration conditions.

Keywords: urban soils, chemical transformation, soil physicochemical properties; humus; plants.

Стаття надійшла 02.07.2019

Прийнято 24.07.2019

(c) О. О. Мислюк, О. М. Хоменко, О. В. Єгорова, В. І. Пидоренко, 2019 DOI: $10.24025 / 2306-4412.2 .2019 .172233$ 